\title{
Don't Hurry to Hootalinqua
}

Quips the sourdough on Lake Laberge.

The current fast, four, five miles an hour.

Be sure to pull off and look:

trappers' cabins, rusted cast irons,

moss-chinked logs carved with names.

Don't rush the Thirty Mile to get

to Dawson. So many have.

Gold-era ghosts rivering the aspens ask us what are you chasing so hard that you're willing to miss U.S. Bend?

Don't hurry to Hootalinqua

past the high honey slopes, bore holes of bank swallows. Wolf willows

line the shore. So quiet you can hear

bumblebees drunk on river beauty.

Don't hurry to Hootalinqua or

you'll miss the best part. 